\title{
El anciano santo del cerro y su cruz. Apuntes sobre el culto al Señor de Quillacas
}

\author{
Francisco M. GIL GARcía \\ Universidad Complutense de Madrid \\ Dpto. de Historia de América II (Antropología de América) \\ fmgilgar@ucm.es
}

Recibido: 25 de marzo de 2015

Aceptado: 26 de octubre de 2015

\section{RESUMEN}

El Señor de Quillacas es una de las imágenes más veneradas en Bolivia, especialmente considerado por su fama de milagrero. Su devoción se encuadra en la lógica del culto a los santo populares andinos, aunque con notables diferencias según asistamos a sus fiestas y homenajes en su santuario principal, en las comunidades del altiplano o en los colectivos de emigrantes. En función de ello, este trabajo presenta un análisis diferencial del santo y su imagen, atendiendo a tres cuestiones clave: 1) el factor milagroso en su culto, 2) la «deformación» del culto a Cristo en su devoción, y su fusión con el culto a los cerros, y 3) la trasnacionalización de su culto en el contexto de la emigración.

Palabras clave: Señor de Quillacas, santos populares, culto a los santos, imágenes religiosas, identidad.

\section{The Holy Old Man of the Cerro and his Cross. Notes on Worshiping the Lord of Quillacas}

\begin{abstract}
The Lord of Quillacas is one of the most venerated images in Bolivia, especially regarded for its reputation as miracle worker. His devotion fits into the logic of the Andean popular saints-cult, although with notable differences according to their festivals and tributes on its main sanctuary, the highland communities, or the migrant groups. So, this paper presents a differential analysis of the saint and his image, according to three key issues: 1) the miraculous factor in their worship, 2) the Christ-cult «deformation» in their devotion, and its merger with the cult to the mountains, and 3) the transnationalization of their faith in the context of emigration.
\end{abstract}

Key words: Lord of Quillacas, popular saints, saints-cult, religious images, identity

Sumario: 1. Introducción. 2. El milagro en el culto al Señor de Quillacas. 3. La «deformación» del culto a Cristo en la devoción al Señor de Quillacas. 4. La trasnacionalización del culto al Señor de Quillacas. 5. Consideraciones finales. 6. Referencias bibliográficas.

\section{Introducción}

Junto con Nuestra Señora de la Asunción de Urkupiña y la Virgen de Copacabana, el Señor de Quillacas es quizás el santo popular más venerado de Bolivia; una imagen en cuya devoción convergen ese catolicismo popular centrado en el culto a los santos y elementos propios de los sistemas religiosos andinos tradicionales. Y sin embargo, de estos tres, es quizás el que menos ha llamado la atención de la etnografía, especialmente dentro de los propios escenarios bolivianos de religiosidad.

En términos generales, baste con señalar que participan del culto a los santos aquellos que están canonizados por la Iglesia católica, pero también aquellos personajes populares que, sin serlo o estando en trámites de beatificación o canonización, reciben veneración popular por considerarse especialmente milagreros o benefactores. Asimismo son englobados en la categoría de santos las diferentes advocaciones de la 
Virgen y de Jesucristo, cada una de ellas individualizada y particularizada en materia de devoción y culto. Desde esta categorización, el Señor de Quillacas se integra al culto a los santos en tanto que advocación de Cristo crucificado, y a la vez por ser objeto de amplia devoción dada su fama de milagrero. Sin embargo, cabe decir que las implicaciones sociales de su culto difieren notablemente si nos ubicamos en la escena rural o en el marco urbano de los migrantes. En el primero de estos contextos se observa claramente lo que M. Marzal (2002) definió en términos de una «deformación del culto a Cristo» como parte del proceso mismo de «santificación», y del que en este caso resulta la figura de un «Cristo-Apu» que vincula el culto a los santos con el culto a los cerros. En el segundo se manifiesta de forma más evidente eso que J. P. Bastian (1997) planteó como «mutación de la religiosidad popular», y que en Bolivia coincide además con un momento de tremenda fluidez en lo religioso; una fluidez que H. Suárez (1999: [26]) interpreta como respuesta adaptativa ante los que denomina «dilemas religiosos en Bolivia», presentes desde siempre aunque agudizados en las últimas décadas. «Dilemas» que, en realidad, viajan con la emigración boliviana a países vecinos, y que a la vez que se constituyen en piedra de toque en los procesos de identificación, expanden el culto a los santos populares y lo convierten en vehículo preferente para la adaptación y la integración social de los emigrados. Pero al mismo tiempo, una expansión del culto, una proyección de la devoción y un viajar de las imágenes que trasnacionalizan los festejos y honores a estos santos, y favorecen el surgimiento de nuevas expresiones, e incluso estéticas, de religiosidad popular.

Las páginas que siguen quedan así planteadas como un intento de analizar las claves de esta doble vertiente en el culto al Señor de Quillacas, antes de lo cual me detendré brevemente en sus orígenes y en la fama de milagrero de este santo.

\section{El milagro en el culto al Señor de Quillacas}

Cuenta la leyenda que en algún momento entre los siglos XVI y XVII un grupo de arrieros cruzaba los parajes de Belén, cerca del pueblo de Sevaruyo, en las pampas de Paria, en Oruro. Entre ellos iba un argentino que llevaba sus mulas a vender o a la feria de Huari o a la de Potosí, según versiones. Acampados en la noche se pusieron a beber, y quedaron dormidos a cuenta de la borrachera. A la mañana siguiente, cuando este arriero argentino despertó se encontró solo, abandonado por sus compañeros y sin rastro de sus mulas. Se puso a buscar sus animales temiendo lo peor, y en ello anduvo durante tres días. Ascendió al cerro San Juan por ver si desde su altura los divisaba ${ }^{1}$, pero nada. Presa de la desesperación, rompió a llorar. Al rato reparó en la presencia de un anciano de barba blanca que lo observaba sentado en unas peñas cercanas. «No llores más -le dijo- y busca tu recua detrás del cerro; allí la encontrarás bebiendo en el arroyo». Así lo hizo, y encontró sus mulas paciendo tranquilas donde le había indicado el anciano. El arriero volvió para darle las gracias, pero en las peñas no encontró sino una cruz con la imagen de Cristo, a cuyos pies estaban

${ }^{1}$ Con sus 3.912 msnm, el cerro San Juan Mallku constituye un excelente mirador desde donde se observan el río Márquez y el río Blanco, el lago Poopó, y la inmensa pampa de Quillacas con sus arenales. Volveré sobre este cerro y su significación más adelante. 
las ropas y la chuspa ${ }^{2}$ del anciano. Lo llevó todo al cercano pueblo de Quillacas ${ }^{3}$ y siguió su camino. Vendió las mulas, obtuvo un buen dinero y volvió a su hogar, pero en todo ese tiempo no dejaba de soñar con el anciano y el Cristo crucificado. Consultó a un especialista ritual que le aconsejó volver a Quillacas y levantar un santuario en honor de la imagen. Se empeñó en la tarea, pero las obras del templo se derrumbaban continuamente. Entonces otro sabio le aconsejó hacer el santuario con planta de cruz. Así lo hizo, y las obras se terminaron sin problema alguno; un santuario con planta de cruz latina, amplia bóveda y un gran atrio provisto de posas, que está considerado hoy entre las joyas de la arquitectura colonial en Bolivia.

A raíz de estos sucedidos, el Señor de Quillacas, Tata Quillacas, pasó a ser tomado como patrono por arrieros y transportistas ${ }^{4}$. Su fiesta, por acople con el calendario agropecuario $^{5}$, se instaló en el 14 de septiembre, coincidente en mes con la Virgen de los Dolores, la Virgen de la Merced o de las Mercedes, el Señor y la Virgen del Milagro, o el Señor de los Milagros, todos ellos igualmente milagreros, y con competencias benefactoras en agricultura y/o ganadería, y para la prosperidad en general.

«Tú eres mi bienhechor, tú me guardaste mi ganado. Te doy gracias, prometo y juro construir en este sitio una capilla para que la gente pueda rendirte homenaje y tú puedas seguir favoreciendo a los necesitados.»

Tal se dice que el arriero agradeció ante la cruz del cerro aparecida en las peñas donde había conversado con el anciano, y tal es la oración que preside el santuario junto a la imagen de un Cristo crucificado de 1,90 metros que en 1860 realizara un orfebre de Potosí. Los devotos que acuden al santuario durante sus fiestas piden a esta imagen bendición, dinero, salud, suerte y bienes. Lo mismo piden al santo los pasantes o promesados de las comunidades rurales, además de solicitar su intercesión en la fructificación de las cosechas, la multiplicación de los rebaños, el cuidado de los ganados y la prosperidad de sus pueblos, pues al fin y al cabo su éxito será el éxito colectivo, repartiéndose los beneficios del milagro entre todos - de la misma manera que la pérdida del favor de los santos y del resto de entidades tutelares se transforma en sucesos infaustos para la colectividad-.Y es que, en este sentido, el milagro actúa como herramienta simbólica para generar mecanismos de cohesión social, al tiempo que para acceder a ciertos espacios y beneficios, o para legitimar posiciones de diferentes sectores o agentes sociales. Dicen que el Señor de Quillacas es un santo harto

\footnotetext{
2 Chuspa: pequeña bolsa tejida, para colgar al cuello, donde se guardan las hojas de coca, que en las celebraciones rituales se intercambia entre los presentes como expresión socializada del compartir.

3 Fundado el 20 de mayo de 1601 por el visitador José de la Vega Alvarado, el pueblo de Quillacas es en la actualidad la cabecera del Municipio Santuario de Quillacas, en la II Sección de la provincia Avaroa, en el boliviano departamento de Oruro.

4 Santo patrón de los transportistas, por efectos del llamado sincretismo, el Señor de Quillacas fue asimilado con San Cristóbal, patrono de los conductores. Es por ello que su nombre e imagen aparecen reproducidos hasta la saciedad en parasoles y banderines que muchos cuelgan de sus vehículos. Asimismo, son llamativas las ch'allas de autos que se celebran en el santuario - como también ocurre en el santuario de la Virgen de Copacabana-, y los largos, coloridos y jacarandosos desfiles de autos que se celebran en la región de Quillacas para las fiestas en su honor.

5 En términos generales para el centro y sur andino, el mes de septiembre, con un equinoccio caracterizado por el aumento de las temperaturas y la disminución de vientos, marca la aparición de los primeros pastos verdes y el tiempo de preparación de los almácigos, de inicio de la siembra de papa y de comienzo de la esquila.
} 
milagrero, pero - en virtud de lo anterior- habría que preguntarse si sus milagros son cosa del santo o de sus imágenes.

Teológicamente el milagro es un signo de Dios, el sustento empírico de la virtud divina, que en su uso social -interpretado y manipulado desde distintas instancias sociales- puede convertirse en símbolo. Así, en su acepción popular el milagro es análogo al prodigio, interpretado o incluso construido a partir de aquello que excede los límites razonables de la naturaleza (Costilla 2007), pero que -como señala M. Marzal (1999: 167)-, podría no ser considerado un signo de Dios por la Iglesia. Esto hace que el análisis del milagro pueda abarcar la variabilidad de interpretaciones de un hecho prodigiosos según su/s beneficiario/s, y establecer correlaciones entre tipos de milagros y sus usos estratégicos (Costilla 2010: 36-37). Pero lo más importante, es que abre la puerta a que los milagros de un santo popular se multipliquen en tanto en cuanto se multiplican sus imágenes, puesto que el contar milagroso en la tradición oral enfatiza (por no decir que se reduce a) aquellas imágenes en concreto que son concebidas por sus devotos como especialmente milagreras; imágenes que tienen capacidades prodigiosas por y en sí mismas, no por ser la representación de tal o cual santo. Por eso hay tanta profusión de imágenes (Colatarci 2000: 8-9). El Cristo venerado en el santuario de Quillacas, con un elevado número de devotos y su propio currículo de milagros, pero también la multitud de cristos o crucifijos venerados en las comunidades altiplánicas o entre colectivos de migrantes, muchos de ellos de propiedad particular o familiar, y con un grupo más o menos discreto de devotos, con su oratorio particular o a los cuales se rinde culto en otros espacios distintos del templo católico; imágenes cada una con su propia hierofanía y su propio historial milagrero, sentidas mucho más propias que el santo mismo o su Cristo de Quillacas, mucho más cercanas a sus devotos. Y esto -como señala J. Costilla (2010: 53)- puede influir en los usos sociales del milagro mucho más que el propio suceso prodigioso.

Pero además, esta multiplicación de imágenes milagreras del Señor de Quillacas permite hablar de eso que H. Velasco (1989) definió como «un replanteamiento de la religiosidad popular como religiosidad local», dotando al culto a los santos de territorialidad y de pertenencia a una colectividad, y fraguando sólidos vínculos entre la comunidad, su imagen, el santo de referencia y unos lugares concretos. Aun cuando el santo tiene poderes que podrían ser considerados universales, las diferentes imágenes, con sus hierofanías y sus milagros, los focalizan sobre un lugar y unas gentes.

Esto hace que el culto al Señor de Quillacas se propague y gane devotos en paralelo a la multiplicación de sus imágenes, pero este mismo fenómeno podría interpretarse como una mengua de la trascendencia, el culto y el poder del santo concentrados en el santuario del pueblo de Quillacas. Sin embargo, me parece que no tiene sentido plantear una polémica entre la primacía de un adoratorio sobre otros, de un culto sobre el resto, de una imagen sobre las demás, ni tampoco establecer una jerarquía de milagros. Cierto es que se podría sacar una cronología de imágenes, milagros o fiestas, pero no es algo que me parezca especialmente útil desde un punto de vista antropológico. Al final, los milagros no hacen sino hablar de la capacidad creativa popular en lo que a búsqueda de auxiliares o patrones se refiere. 


\title{
3. La «deformación» del culto a Cristo en la devoción al Señor de Quillacas
}

\begin{abstract}
«[Cristo] Es el anciano santo del cerro que restaura el equilibrio del mundo. [...]. A alguien ajeno a esta síntesis le resultará difícil reconocer a Jesús de Nazaret (en muchas imágenes rubio y con ojos azules) en el anciano Quillacas, o no terminará de entender su función ritual junto a los demás santos. Sólo un corazón en sincera búsqueda de Cristo puede descubrir su nueva presencia en medio de la realidad de los Andes» (González, Pliego y Beriain 2005: 51).
\end{abstract}

Llámese heterodoxia, sincretismo ${ }^{6} \mathrm{o}$, como hicieran sus extirpadores en época colonial, idolatría. El caso es que en el catolicismo popular se mezclan -por no decir que se confunden, ya que en realidad se funden- la persona de Cristo, la Virgen y los santos con sus imágenes; no como alegorías, sino como objetos de culto directo, convertidas entonces en nuevas wakas para las gentes de los Andes. De ahí que entre los evangelizadores de las Indias cundiera el dilema de si los indios simplemente adoraban a las imágenes o realmente veneraban a quienes éstas representaban. Conjugando entonces cánones oficiales y tradiciones populares, y considerando a un mismo nivel imágenes y personas de referencia, el culto a los santos se compondrá quizás como la manifestación más extendida de dicho catolicismo popular.

Como el resto de santos populares, el Señor de Quillacas ejerce de intermediario entre el plano de existencia del aquí y ahora en que habitan las gentes del altiplano, y ese otro mundo de «las alturas» donde moran Dios, los apus y los cuerpos celestes, con quienes éstas interactúan según las reglas de reciprocidad que determina el pago de ofrendas en el contexto de un costumbre. De este modo los «poderes metapastorales» del santo quedan plasmados en el espacio-tiempo de un paisaje vivo. En este sentido, y sin perder de vista su tutela sobre los ganados, el Señor de Quillacas remite a un Cristo entendido como santo-imagen materializado en una cruz, que se transforma en Cristo- $a p u$ cuando el Divino Pastor se funde con el «dueño del cerro» y pastorea entonces tanto a los ganados como a los seres humanos. Y es que desde la aparición misma del venerable anciano del cerro a aquel arriero desesperado, y de su transformación en imagen de Cristo en la cruz, en el culto que nos ocupa confluyen elementos propios del catolicismo popular y de los sistemas religiosos andinos; elementos manejados de manera diferenciada de acuerdo con la naturaleza de los espacios ceremoniales implicados en la celebración del rito y la fiesta. Concebido entonces desde esta doble lógica como santo y como entidad tutelar, el Señor de Quillacas ordena la naturaleza y la vida social de la colectividad, derivando su acción benefactora en expresión de buena fortuna y prosperidad según la lógica redistributiva antes señalada.

Fruto de esta fusión de creencias católicas y tradicionales, y aplicando la terminología de M. Marzal (2002), el culto al Señor de Quillacas - como el del conjunto de santos populares- mantiene una doble faceta «pastoral» (oficios religiosos, rezos, plegarias, procesiones) y «local» (rituales, costumbres, ofrendas, libaciones), que

\footnotetext{
6 Nada más lejos de mi intención que perderme en la discusión del concepto mismo de sincretismo religioso -al que M. Marzal (1985) dedicara un libro convertido ya en un clásico para la escena latinoamericana en general y andina en particular-, remitiendo para una actualización de la misma al estimulante trabajo de M. Gutiérrez (2013).
} 
queda expresada asimismo en la concurrencia de diferentes espacios ceremoniales cargados de significado propio desde una u otra. Mientras que a la primera corresponden la iglesia y sus aledaños «cristianizados», a la segunda lo hacen los escenarios domésticos y de los cerros. Todo ello porque en realidad el Señor de Quillacas es un santo-imagen cuando resulta venerado en su representación de Cristo crucificado, pero es al mismo tiempo un Cristo-apu cuando se le atiende como a una entidad tutelar más, sin que esta ambivalencia de naturalezas y simbolismos implique para los andinos problema alguno en términos ontológicos, éticos o de fe.

Pero además de ello, es que podría decirse que realmente el Señor de Quillacas es uno y múltiplo a la vez. Se reconoce un Cristo, llamémosle «original», el que según la leyenda se apareció a aquel arriero en el paraje de Quillacas en el tránsito de los siglos XVI-XVII, y en honor al cual se levantó el santuario homónimo. Pero -según lo ya comentado- al margen de éste, cada comunidad tendrá su propio Señor de Quillacas -o incluso más de una imagen suya-, con su propia hierofanía, su propia historia local, aquella que lo legitima y que permite a sus fieles reconocerlo y sentirse identificados en él, amparados por él. Este sentir al santo patrón como propio y cercano es lo que favorece que tanto su figura como su fiesta sirvan para la exaltación identitaria, como más adelante abordaré. Por este motivo es tan popular y arrastra a tantos devotos, en Bolivia y fuera de sus fronteras.

Sin entrar en pormenores sobre el tema, pensemos en la conquista espiritual de las Indias como una dinámica que en cierto sentido dejó a los indígenas «huérfanos» en lo sagrado: la extirpación de idolatrías (presuntamente) acabó con sus wakas y deidades, dejando vacantes unos espacios que fueron entonces rellenados con un nuevo Dios trinitario, vírgenes y santos, que asumieron así personalidades y conductas más cercanas al mundo indígena, y a veces incluso bastante alejadas de la hagiografía canónica y hasta del dogma. La comunión entre este nuevo panteón y el paisaje andino se impuso como algo indispensable. Estas nuevas figuras se reacomodaron a las tradiciones locales, más aún cuando en las comunidades era frecuente que hubiera iglesia pero no cura; y así sigue siendo, por otro lado, en muchos lugares apartados. Las imágenes sagradas, lejos de ser entendidas como meras alegorías, empezaron a ser identificadas con la divinidad y a recibir culto directo. La fiesta de los diferentes santos patrones de la comunidad se convirtió en pieza clave para el ordenamiento calendárico. Estos santos patrones, o mejor dicho, sus imágenes, asumieron la identidad de sus pueblos, desde los cuales se compuso su propia historia local y regional, aquella que las legitimaba y que les permitía ser reconocidas por sus fieles. Convertidas entonces en objeto sagrado en sí mismas y no tanto por aquél o aquello que representa, el culto a las imágenes de estos santos patrones se tornó prontamente funcional según los parámetros de la cultura local, y los comuneros empezaron a comportarse con ellas de igual manera que con sus antiguas wakas y con las entidades tutelares tradicionales, estos es, desde la reciprocidad. A través de esta lógica, las imágenes pronto pasaron a guiar el destino de sus pueblos, de tal modo que los logros obtenidos pasaron a de entenderse como milagros, y los sucesos infaustos como castigos (Marzal 2005: 155-160; Millones 1998).

Muchos entenderían esta argumentación como evidencia patente de un sincretismo fundamentado en engaños y argucias por parte de unos indios que así, enmascarando 
sus tradiciones idolátricas con pinceladas de cristiandad, consiguen mantener vivas sus antiguas prácticas. Sin embargo -coincidiendo con C. Bernand y S. Gruzinski (1992: 151-152) en su valoración del culto a los santos en el contexto revisado del sincretismo religioso-, no veo por qué seguir empeñándonos en ello en vez de aspirar a ver las cosas como resultado de un mestizaje en el que la herencia indígena se fundió con los elementos católicos (canónicos y populares) introducidos por los europeos, resultando de ello un nuevo producto que, como expresión de cultura viva, el paso del tiempo ha ido reinterpretando y reacomodando a nuevas necesidades y tradiciones. La retroalimentación entre «lo cristiano» y «lo andino», señala T. Abercrombie (2006: 161-162), parece haber sido tan intensa que tratar de distinguir lo uno de lo otro no tendría sentido. El quid de la cuestión está en que el santo atienda a sus devotos, y si lo importante es atraer su atención, ¿qué problema hay en usar para ello todos los medios disponibles, cuantos más mejor, a fin de asegurarse el éxito? A fin de cuentas, el Señor de Quillacas es un santo que es un Cristo, que en realidad es su cruz, que al mismo tiempo es un «señor de los ganados» ${ }^{7}$, y que incluso, a todas luces, podría ser el propio cerro. Ahondaré en este punto.

A pesar de que entre Cristo y los santos hay tremendas diferencias ontológicas, el catolicismo popular (el mestizo como el europeo) no establece diferencias simbólicas, puesto que uno y otros son imágenes; tampoco de culto, ya que a ambos se ofrecen pagos y promesas a cambio de milagros o ayudas (Marzal 2002: 324-325, 379). Para la Iglesia, Cristo es el único mediador entre Dios y los hombres, y en tanto que Hijo del Padre recibe su misma adoración y gloria, tal y como reza la oración del Credo; santos y vírgenes, en cambio, sólo recibirían devoción y veneración, por más que el catolicismo popular, a través del culto a los santos, ignore esta diferencia dogmática (Marzal 2002: 320, 325). La incorporación de Jesucristo al sistema religioso andino lo convierte en Taytacha (quechua) o Tatala (aymara), «nuestro pastor padre», Agnus Dei (Cordero Pascual) y pastor de hombres a la vez, que, investido de «poderes metapastorales», cuida de sus rebaños (animales y humanos) y fertiliza sus campos de cultivo, dueño del espacio y el tiempo sociales con el que se imponen la necesidad de negociar desde esa lógica de reciprocidad que articula las relaciones con unas entidades tutelares andinas que suelen ser bondadosas y crueles al mismo tiempo (Abercrombie 2006: 427-430).

Desde esta perspectiva, el Cristo-santo asume las mismas facultades que desde el pensamiento local corresponden al apu, la entidad tutelar del cerro, no en el sentido de una deidad que habita en la montaña, sino haciendo que apu y cerro sean la misma

\footnotetext{
7 No existe en el mundo andino una asociación precisa entre santos patrones y ganados, sin que realmente se busquen entre los primeros aquellos con unas características o facultades especiales que los hagan más o menos interesantes o apropiados para establecer un vínculo con los animales. Para el caso de la sierra peruana y en particular el valle de Chancay, J. J. Rivera (comunicación personal) explica los vínculos de Santiago y San Miguel Arcángel con el ganado vacuno por el hecho de que el imaginario popular presupone a los bóvidos las connotaciones bélicas propias de ambos santos. Sin embargo, para el altiplano aymara boliviano, V. Ochoa (1988: 151) señala la especial relación que se establece entre la Trinidad y los santos Marcos e Isidro con el ganado vacuno, de la misma manera que entre san Juan y las ovejas, san Antonio y las llamas y alpacas, y santa Inés y los cerdos. Significativamente, los trabajos sobre religiosidad popular nunca mencionan el fuerte vínculo que en el altiplano sur se estrecha entre el Señor de Quillacas y los ganados, quizás porque su traslación al mundo urbano en contextos migratorios ha derivado en que su fama de milagrero se imponga sobre el resto de sus poderes.
} 
cosa: una entidad tutelar, un jefe (mallku), la fuerza ordenadora del paisaje culturizado, dueño de los animales y plantas que crecen en sus laderas (espacios salvajes), de los pueblos, los sembradíos y los corrales de ganado (espacios domesticados). Un cerro que se convierte, como detalla X. Ricard (2007: 53-75), en «pastor de hombres». A él corresponde, junto a la Pacha Mama, el papel de ordenador, guardián y fertilizador; por eso se apela a él para llamar a las lluvias (fuente de vida), que a su vez devendrán en prosperidad, en bonanza para la comunidad. Teniendo en cuenta que los cerros (masculinos y femeninos) son entendidos desde el imaginario de un paisaje antropomorfizado, la relación biunívoca entre apu y cerro es articulada de acuerdo con las mismas reglas metafóricas y metonímicas que la establecida entre santo e imagen: se crea una unidad simbólica que polariza la atención de los devotos, anima sus deseos y esperanzas, y canaliza sus expectativas, haciendo que la referencia de orden material (cerro, imagen) pueda visualizarse y, a partir de ahí, favorecer una interrelación directa. Por este motivo, señala M. Marzal (2002: 280-282, 411412), los apus van a ser cristianizados y santificados en calidad de «intermediarios/ santos andinos»: entidades que Dios pone en el paisaje para vigilar y proteger a las comunidades, para premiarlas o castigarlas, «realidades sagradas que alimentan a los hombres de parte de Dios», y a las que por esta razón hay que mantener atendidas y satisfechas.

Al fusionar a Cristo con el apu, el primero pasa no sólo a habitar los espacios del cerro, sino a convertirse en el cerro mismo. Opera así lo que R. E. González, M. Pliego y F. Beriain (2005: 51) entienden como su conversión a la Fe originaria de los Andes, resultado de la cual «Cristo ya no tiene sólo un rostro indígena. También tienen un corazón y una fe originaria». Por este motivo en el catolicismo popular no existe un único Jesucristo ajustado al dogma cristiano, sino diferentes cristos, cada uno asociado a su correspondiente paisaje sagrado, cada uno con sus propios espacios ceremoniales, cada uno con su particular currículo milagrero ${ }^{8}$. Por tanto, de la misma manera que el santuario, la capilla o la iglesia de turno definen un espacio ceremonial concreto dentro del culto y la fiesta de cada Cristo-santo-imagen (espacio católico domesticado), desde los cerros se componen unos paisajes definidos por la presencia del Cristo- $а р и$ (espacio tradicional salvaje), cada uno de ellos articulado respectivamente según una lógica espacial y ceremonial particular9

Volviendo a la primera hierofanía del Señor de Quillacas, no es entonces de extrañar que aquel venerable anciano que auxilia a ese arriero que ha perdido sus animales se aparezca en las alturas del cerro San Juan Mallku, bajo cuya tutela se instala la

\footnotetext{
8 En este sentido, la fama del Señor de Quillacas radica en su origen hierofánico, completándose así una asociación de sentidos entre Cristo, el cerro, el santo milagrero y la imagen igualmente milagrera, como ocurre - cada cual en sus variantes-con otros cristos (o señores) americanos como el de Chalma (estado de México), de Tila (Chiapas), de Esquipulas (Guatemala), de Bomfín (Salvador de Bahía), de los Milagros (Lima), de los Temblores (Cuzco), de Qoyllurrit'i (Quipiscanchi), de Huanca (Calca), de Locumba (Tacna), del Gran Poder (La Paz), del Milagro (Salta y Corrientes), etc.

9 Tomando como referente esta figura del Cristo-apu particularizada desde los cerros tutelares de cada comunidad, ya dediqué otras páginas (Gil 2010) al análisis espacial del culto al Señor de Quillacas en la población de Santiago (Nor Lípez, Potosí, Bolivia), distinguiendo entonces la casa del pasante, la iglesia y el cerro como tres escenarios de ritualidad bien diferenciada, en los cuales los elementos católicos y andinos o bien se (con)fundían, o bien resultaban exclusivos y a la vez excluyentes.
} 
población de Quillacas. En él se han encontrado adoratorios prehispánicos -lo que en cierta medida corroboraría esa idea de la continuidad de creencias bajo nuevas imágenes y cultos, pero manteniendo espacios ${ }^{10}-$, y aparece además vinculado a uno de los ciclos míticos más relevantes del altiplano surandino: la epopeya de Tunupa. Muy a grandes rasgos (ver Juanez 1991: 1-40), Tunupa era una pastora de inigualable belleza que vivía a orillas del Titicaca, a la que todos deseaban y envidiaban a la vez, pretendida por varios titanes -todos ellos imponentes montañas de la Cordillera Occidental-. Tras ser ultrajada por uno de ellos, se vio condenada a errar por el Collao, primero en cinta y después cargando con su hijo recién nacido; tras sufrir penalidades diversas, el niño finalmente moriría en el paraje de los arenales de Quillacas, dicen que justo en el lugar donde hoy se levanta el santuario del Señor de Quillacas, y ella lo haría poco después en la orilla norte del Salar de Uyuni, convirtiéndose en majestuoso volcán. Evidentemente, a lo largo de este periplo Tunupa contribuyó a componer el paisaje a su paso, siendo así que este cerro San Juan Mallku resultó de las piedras que la diosa amontonó para encender un fogón donde cocinar (Molina 1996).

Según indica T. Gisbert (2004: 27), el cerro también es nombrado en la toponimia local como Mallku Juan o Mallku Juan Quillacas, y a todas luces éste se encarnaría en el anciano venerable que indicó al arriero imprudente dónde encontrar sus animales, y que luego se transformó en cruz de Cristo. Una encarnación del dueño del cerro, guardián (pastor) de los animales que pastan en sus laderas, que redondea esta caracterización del Cristo-apu: aquel que, convertido en santo popular (quizás incluso un santo patrono), ordena la naturaleza y la vida social de las comunidades bajo su tutela.

\section{La trasnacionalización del culto al Señor de Quillacas}

Aunque su fama de imagen milagrera no tardó en propagar su devoción entre el conjunto de la sociedad, el culto y las fiestas al Señor de Quillacas, sin embargo, no se popularizarían hasta el siglo XIX, cuando empezaron a proliferar capillas y adoratorios a él consagrados; fue entonces cuando pasó a situarse entre los santos patrones de muchas comunidades altiplánicas. Con todo, la masificación de su culto, sus fiestas y la peregrinación al santuario de Quillacas no llegarían hasta el siglo XX, convirtiéndolo en objeto de culto nacional en Bolivia, y en imagen viajera de honda devoción en el sur andino. En virtud de estos fenómenos la tradición y las fiestas del Señor de Quillacas fueran incluidas en el Patrimonio Oral, Cultural y Religioso de Bolivia por Ley $\mathrm{N}^{\mathrm{o}} 3705$ de 5 de julio de 2007. Por su relevancia histórico-artística, la Ley $\mathrm{N}^{\circ} 2979$ de 10 de febrero de 2005 ya había declarado Bien de Patrimonio Cultural de la Nación el Santuario del Señor de Quillacas, también conocido como Santuario Internacional dedicado al Cristo de Quillacas, una nomenclatura que remite a la trasnacionalización de este santo popular.

\footnotetext{
10 A este respecto me parece a destacar el hecho de que la significativa presencia de rocas meteóricas en los arenales de Quillacas hayan valido a esta población el sobrenombre de "ciudad mágica del meteorito», siendo ésta la razón por la cual, en virtud de ciertas teorías sobre concentración de la energía cósmica en el paisaje, Quillacas se ha convertido de un tiempo a esta parte en foco de atracción para otro tipo de «creyentes».
} 
Ejemplo del hondo calado social del culto a esta imagen en Bolivia puede verse en la persona del presidente Evo Morales, devoto confeso de un Tata Quillacas al que afirma rezar diariamente, que llegó a asegurar públicamente que «es muy grande [su poder], por eso podemos seguir con vida. Así como de niño me dio vida para estar sano, le pido ahora que me dé vida para seguir trabajando por el pueblo boliviano; es el único deseo que tengo» (ABI, F3278, 03.08.2009). Durante el transcurso de una misa oficiada en el santuario de Quillacas el 3 de agosto de 2009, el Presidente fue bendecido «para que siga llevando a Bolivia por el sendero del progreso y la prosperidad» y «para consiga su pareja», agradeciendo éste la bendición y pidiendo para que se hiciera extensiva a todo el pueblo boliviano (ABI, F3255, 03.08.2009). Recordando su infancia, las muchas peregrinaciones que junto a sus padres realizó el lugar, y cómo el santo obró el milagro de su curación a la edad de siete años, el presidente Morales declaró creer «en el Tata Quillacas, en la religión, en las distintas iglesias reconocidas ahora por la Constitución, creo en los padres pastores que rezan y oran por la justicia, por la libertad» (ABI, F3278, 03.08.2009) ${ }^{11}$. Devoción o demagogia, cada cual que piense lo que quiera. El caso es que la devoción popular al Señor de Quillacas creció notablemente después de que Evo Morales ganara las elecciones presidenciales de 2005 gracias a que -según el mismo ha confesado en repetidas ocasiones- peregrinó hasta su santuario para ofrecer al santo unas velas y pedirle por ello.

Sin embargo -como señalé al principio de este texto-, no deja de resultar llamativo que, pese a ser una advocación de Cristo de gran devoción en Bolivia, a su fuerte raigambre popular ligada al ganado, a ser un santo que el presidente Morales ligara a la prosperidad del país, el Señor de Quillacas apenas ha llamado la atención de los etnógrafos que trabajan en el campo boliviano, y su imagen tienda a resultar exigua en los estudios sobre religiosidad popular y culto a los santos.

Por el contrario, su nombre sí adquiere especial relevancia en la bibliografía que aborda su culto desde la perspectiva de la construcción identitaria y el mantenimiento de redes sociales a partir de los vínculos de Fe entre migrantes bolivianos que residen en el norte de Chile o el sur de Perú, y muy especialmente en el noroeste de Argentina (Colatarci 1984, 2000, 2009; Guzmán 2006a, 206b, 2009; Rubinelli 2000; Sadir 2001). En estos otros contextos urbanos la fiesta ha olvidado el componente ganadero y ha perdido su naturaleza de costumbre, para transformarse en un eje vertebrador de relaciones sociales y familiares expatriadas. El culto al Señor de Quillacas se redimensiona, y es entonces cuando su fiesta, a través de cofradías y comparsas, adquiere

11 A este respecto, no habría que olvidar que Evo Morales, a pesar de decirse católico -amén de practicante del culto a la Pachamama, que considera la creencia de sus antepasados-, ha tenido varios enfrentamientos con la Iglesia Católica desde que asumió la presidencia de Bolivia en 2006, los más graves en el tránsito de 2008 a 2009, en plena campaña por el proyecto de reforma constitucional. Durante estos meses fueron muchas las voces que desde el oficialismo, la oposición y el propio Gobierno se lamentaron de que la Iglesia pretendiera ingresar en política y de que ciertos miembros de su alta jerarquía estuvieran politizando la prédica y la oración. Sobre estas críticas volvería el propio Morales en su discurso del 3 de agosto de 2009 en el Santuario de Quillacas, enfatizando que «eso no es trabajar por la justicia, por la igualdad que predicó nuestro Jesús» (ABI, F3278, 03.08.2009). Ya en enero de ese mismo año el propio Morales había acusado a la Iglesia boliviana de ser una marioneta del imperialismo, y a sus jerarquías de obstaculizar el cambio en Bolivia, pidiendo entonces una nueva Iglesia y una nueva Fe. 
nueva carta de naturaleza: por un lado favorece el establecimiento de unos vínculos de fe entre los migrantes, que se transforman en redes asistenciales de primer orden (Guzmán 2006b); y al mismo tiempo despliega todos los elementos necesarios para expresar la distinción identitaria en torno al culto al santo y a su imagen (Guzmán 2006a). Todo ello en el marco de lo que $\mathrm{M}^{\mathrm{a}} \mathrm{A}$. Colatarci (2009) presenta como devociones y celebraciones de frontera, y que $\mathrm{M}^{\mathrm{a}} \mathrm{L}$. Rubinelli (2000) analiza desde el ordenamiento simbólico del espacio-tiempo. Y es que el culto al Señor de Quillacas resulta un claro ejemplo de eso que J. P. Bastian (1997) define como «mutación religiosa de América Latina»; una mutación del culto a los santos que, por efecto de los fenómenos migratorios, se trasnacionaliza, lo que a su vez genera nuevas mutaciones. En este sentido, las expresiones de religiosidad popular, en tanto que mantenedoras de la cohesión social, forman parte de los «mecanismos de defensa de los marginados frente a la anomia endémica» (Bastian 1997: 90), dando cobertura al mantenimiento de lazos comunitarios que logran la circulación de esas solidaridad y reciprocidad tan necesarias para enfrentar el medio hostil que representan la emigración, la marginalidad, la pobreza; lazos comunitarios que se estrechan a partir de las fiestas religiosas, las cofradías, el compadrazgo (Bastian 1997: 39-40). Por todo ello -señala J. A. Guzmán (1990: 94)-, las celebraciones en honor del Señor de Quillacas se presentan como el momento y el lugar idóneos en el que se producen una multiplicidad de interacciones sociales que marcan identidades, jerarquías y niveles de distinción, tanto al interior del grupo pero también al exterior.

Como ya he señalado, si bien para estos colectivos de migrantes se mantiene el referente del santuario de Quillacas en Bolivia, en estos otros escenarios de culto trasnacionalizado suele operar la modalidad de oratorios particulares (Colatarci 1984, 2009: 560-561), de manera que cada una de las imágenes veneradas es de propiedad particular, y las celebraciones en su honor por un grupo más o menos cerrado de devotos entre los cuales se estrechan relaciones sociales y/o parentales preexistentes. Sólo en ocasiones la fiesta congrega a varios poseedores de imágenes de esta misma advocación cristológica, abriéndose entonces la fiesta a la competencia entre imágenes -y aquí el currículo milagrero de cada una se tornará en arma fundamental-y entre grupos de devotos, y al festival de comparsas. Comparsas que -como presenta J. A. Guzmán (2006a, 2006b) - poco a poco irán ganando presencia en los festejos de Carnaval o Fin Año, en la celebración de las fiestas patrias bolivianas en los lugares de acogida de los colectivos migrantes. Asimismo, grupos de devotos que irán estrechando a la vez sus vínculos sociales más allá del vínculo de Fe que los une, convirtiéndose en agrupaciones a las que con el tiempo se sumarán amigos y vecinos, y cuya infraestructura terminará al servicio de reuniones y celebraciones diversas (Guzmán 2006b: 59).

Fruto de esta mutación de lo religioso, en la interacción que genera la festividad en honor al santo los devotos construyen simbólicamente la imagen que tienen de sí mismos, posicionándose frente a los otros, y a la vez convertidos en objeto de atención por parte de éstos. En este sentido, ser devoto de tal o cual imagen implica no sólo participar de sus celebraciones, sino hacer que éstas se constituyan en un «lugar» a través del cual poder ejercer y (re)actualizar tanto sus trayectorias personales, como los nexos que los unen como grupo (Guzmán 2006a). Y aquí es donde la construcción 
y la expresión de las identidades se tornan en derivados fundamentales del culto al Señor de Quillacas, como también ocurre para el resto de santos populares trasnacionalizados. La sociedad argentina tenderá a otorgar a todos los devotos una identidad homogeneizante y reduccionista como «bolivianos» a partir de las danzas, la música, la presencia de la bandera boliviana, sin olvidar, por supuesto, la procedencia del culto y la «nacionalidad» del propio Señor de Quillacas. De la misma manera, éstos buscarán estrechar una relación internacional, por ejemplo a partir de banderas argentinas, cintas con los colores de la bandera tanto boliviana como argentina, billetes simbólicos de ambos países que serán entregados a modo de ofrenda al santo o presente a sus pasantes, o vistiendo ponchos de gaucho, todo ello con el propósito de dar cuenta del sentimiento de migración y de la manera en que se (re)elabora el sentido de nacionalidad a partir de una expresión de Fe (Guzmán 2006a, 2009: 102). Una distinción identitaria que resulta enfatizada cuando estos devotos acuden «como bolivianos» a la ciudad argentina de Salta para participar en las celebraciones al Señor del Milagro ${ }^{12}$ con sus propias imágenes del Señor de Quillacas, o cuando se diferencian y muestran «como argentinos» al peregrinar al santuario de Quillacas en Bolivia (Colatarci 2009: 560-561).

Desde esta perspectiva, si, por efecto de la metonimia, el Señor de Quillacas es en cierto modo reemplazado por sus imágenes, cabría hablar de diversidad de cultos al margen de una suerte de norma, de una variabilidad de folklore y tradición desde la cual se sustentan y modelan diferentes performances rituales (Guzmán 2006a, 2009). El culto a cada imagen del Señor de Quillacas ofrece a su grupo de devotos la posibilidad de una respuesta adaptativa a y vinculante con su entorno particular, lo que posibilita la producción propia de nuevos comportamientos religiosos. Una parte de la expresión, el simbolismo y el ritualismo que marca las celebraciones al Señor de Quillacas resultará entonces heredera de lo que podríamos llamar modelo boliviano más ortodoxo (el del santuario de Quillacas, pues recordemos que en las comunidades rurales también proliferan las imágenes y los cultos particularizados), pero el resto resultará propio de cada imagen, de cada colectivo: el himno al Señor de Quillacas, los escenarios de la celebración, la decoración, la utilería, todo aquello que dé sentido a la participación de los devotos en $s u$ fiesta y en las relaciones con $s u$ imagen. Unas imágenes -señala J. A. Guzmán 2009: 94-95)- que deben ser traídas desde Bolivia, pero que no se compran, sino que se pasan de una persona a otra como promesa, pues parte del agradecimiento es dar a conocer a otros el alcance milagrero del santo. Unas imágenes que se pasan entre personas que ya mantienen una relación familiar o de parentesco ritual (compadres, padrino/madrina, ahijado). De este modo -insistiré en ello- los lazos del grupo se refuerzan, la identidad construida en torno a la imagen se refuerza, la singularidad del culto a cada imagen se refuerza. Y todo ello gracias a una obligación moral, un compromiso con la imagen y con el propio

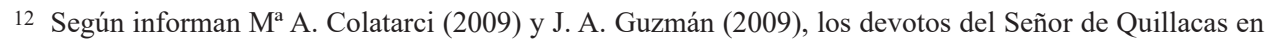
la provincia argentina de Jujuy suelen acudir a la ciudad de Salta para participar en la celebración al Señor del Milagro, ya que consideran que ambos cristos son el mismo. Si bien esta asociación de santos populares abre una interesante línea de análisis en el estudio de las devociones populares a Cristo, y en su propia concepción y representación desde el pensamiento mestizo (o sincrético) en América Latina, no transitaré por ella en esta ocasión. 
grupo de devotos. Es el pasante quien, generalmente cumpliendo con una promesa, organiza la fiesta o el costumbre, asumiendo los gastos (o buena parte de los mismos) de ornamentación, banquete, bebida, música, etc. Para ello, no es extraño que cuente con el apoyo económico de uno o varios padrinos - un vínculo frecuentemente reforzado a través de relaciones de compadrazgo-. Del mismo modo, también suele contar con colaboradores que le ayuden en la organización y el desarrollo de la celebración. Todos ellos van a ocupar un papel protagónico en la fiesta, más o menos visible y más o menos próximo (en términos espaciales) al pasante o la presidencia según sus cometidos particulares. Una ayuda, una visita, un servicio, una acción social, una muestra de cortesía, actuaciones que consolidan el sistema jerárquico y estructurante del «grupo de fe».

Es esta dimensión social del culto al Señor de Quillacas (a los santos populares en general), la que explicaría su arraigada presencia entre los grupos de migrantes, y al mismo tiempo estaría estimulando la canalización de acciones y relaciones sociales hacia el culto popular. Según plantea N. Tassi (2012: 286-287), el culto a las imágenes y la fiesta de los santos populares cada vez es más «propiedad» de sus devotos, de las familias, de los barrios, mientras que la Iglesia pierde su control sobre todo ello, llegando incluso a entrar en un conflicto de intereses. Mientras para los devotos las celebraciones al Señor de Quillacas basculan entre la veneración religiosa y la exhibición material, la Iglesia tiende a considerarlas como expresiones de una religiosidad popular distorsionada o malinterpretada, e insiste en la necesidad de despojar a la celebración de sus excesos paganos: consumo de alcohol (en particular de chicha), pagos rituales, referencias a la Pachamama, papel picado, música y baile. Con todo, a efectos de legitimidad, el culto popular siempre acabará buscando el respaldo de la Iglesia y cierto vínculo con el culto oficial a través de misas, novenas o bendiciones (Guzmán 2009: 104-105).

\section{Consideraciones finales}

Como el resto de santos populares, el Señor de Quillacas ejerce de intermediario entre el plano de existencia del aquí y el ahora en que habitan sus devotos, y ese otro mundo de «las alturas» donde moran Dios, los apus y los cuerpos celestes, con quienes éstas interactúan según las reglas de reciprocidad que determina el culto a los santos, mezcla de elementos del catolicismo popular y los sistemas religiosos andinos, que son manejados de manera diferenciada de acuerdo con la naturaleza de los espacios ceremoniales implicados en la celebración del rito y la fiesta. Una conjunción de elementos que refuerza los poderes metapastorales del santo y hace que el Señor de Quillacas, en su santuario, en las capillas y/o calvarios rurales, o en las imágenes veneradas por quienes emigran y los llevan de viaje consigo, influya sobre gentes, rebaños y campos de cultivo; posibilita que su acción benefactora prodigue buena fortuna y prosperidad para sus devotos, y, por extensión, sobre sus comunidades/colectivos.

Expresiones religiosas como las del Señor de Quillacas son performance, porque se ponen a sí mismas en juego. Los acontecimientos que sirven como medios de co- 
municación de su culto y su devoción (como las fiestas y celebraciones oficiales, las festividades colectivas, las procesiones, las peregrinaciones, los homenajes particulares, los rituales, los costumbres, los pagos, las bendiciones), no son en realidad ni un reflejo ni una ilustración de una cultura popular; forman parte, por el contrario, de las prácticas a través de las cuales una cultura se (re)crea y se transforma. Es por ello que los santos populares, sus imágenes, se inscriben en la memoria social local o grupal.

En este sentido, si las expresiones del culto al Señor de Quillacas son diversas en virtud de los múltiples escenarios sobre los que éste se proyecta, convendría profundizar en la búsqueda de sus orígenes; en el estudio de sus áreas de difusión; en las referencias al lugar de origen y a los paisajes propios de cada una de ellas, pero también al lugar de origen de los devotos, y de las imágenes veneradas; en el análisis del rito y sus formas en cada escenario, en cada espacio ceremonial particularizado; en la observación del dinamismo de las manifestaciones religiosas populares; en las formas de percepción de la santidad (popular); en la dimensión milagrera del santo $\mathrm{y}$, especialmente, de sus imágenes, así como en su actuación protectora y/o benefactora. Convendría profundizar en todo ello, en conjunto o por separado, para tratar de equiparar el conocimiento etnográfico sobre el culto al Señor de Quillacas con la devoción que se le practica tanto dentro como fuera de Bolivia. Tal ha sido el propósito de estas páginas, meros apuntes sobre los que sigo trabajando.

\section{Referencias bibliográficas}

ABercrombie, Thomas A.

2006 Caminos de la memoria y el poder. Etnografia e historia de una comunidad andina [1998]. La Paz: Institut Français d'Études Andines - Instituto de Estudios Bolivianos - Cooperación ASDI-SAREC.

ABI (Agencia Boliviana de Información) www.abi.bo/abi/

BASTIAN, Jean Pierre

1997 La mutación religiosa de América Latina. México: FCE.

BERNAND, Carmen y Serge GRUZINSKI

1992 De la idolatría. Una arqueología de las ciencias religiosas [1988]. México: FCE.

COlatarci, Ma Azucena

1984 «Culto y celebración del Señor de Quillacas», en Actas del encuentro de investigadores de folklore, Augusto Raúl Cortázar, comp., pp. 185-203. Salta: Universidad Nacional de Salta - Instituto Salteño de Cultura Hispánica.

2000 «El contar milagroso en la tradición oral del NOA». Mitológicas 15: 7-18.

2009 «Devociones y celebraciones de frontera en la República Argentina». Anuario [de la Universidad de Ciencias y Artes de Chiapas] 2009: 551-568.

Costilla, Julia

2007 «Los usos sociopolíticos del milagro cristiano. Una aproximación teórica y bibliográfica», en XI Jornadas Interescuelas/Departamentos de Historia. Tucumán: Universidad Nacional de Tucumán. 
2010 «El milagro en la construcción del culto a Nuestra Señora de Copacabana (virreinato del Perú, 1582-1651)». Estudios Atacameños. Arqueología y Antropología Surandinas 39: 35-56.

Gil García, Francisco M.

2010 «De casa al cerro pasando por la iglesia. El culto al Señor de Quillacas en una comunidad de Nor Lípez (Potosí, Bolivia)». Revista Española de Antropología Americana 40 (1): 261-286. Madrid.

GISBERT, Teresa

2004 Iconografia y mitos indígenas en el arte [1980]. La Paz: Editorial Gisbert y Cía.

GonzÁlez, Roberto E., Manuel Pliego y Fernando Beriain

2005 «La conversión de Jesús a la fe originaria andina. Proceso de síntesis vital en el encuentro de dos revelaciones», en Por los muchos caminos de Dios. III. Teología latinoamericana pluralista de la liberación, José María Vigil, Luiza E. Tomita y Marcelo Barros, coords., pp. 42-51. Quito: Abya-Yala.

GutiÉRrez Estévez, Manuel

2013 «Otra vez sobre sincretismo», en Los rostros de la Tierra encantada. Religión, evangelización y sincretismo en el Nuevo Mundo, José Sánchez Paredes y Marco Curatola, eds., pp. 503-522. Lima: PUCP-IFEA.

GuZMán, Juan Armando

2006a «Las distinciones identitarias que generan una actuación religiosa», en Actas de las X Jornadas Nacionales de Investigadores en comunicación. San Juan.

2006 b «La festividad religiosa como signo de identidad: migrantes bolivianos en Jujuy». Cuadernos de la Facultad de Humanidades y Ciencias Sociales 31: 53-66. 2009 «Hacia un encuadre metodológico de las actuaciones culturales/religiosas. Sobre el caso del Señor de Quillacas». Cuadernos de la Facultad de Humanidades y Ciencias Sociales - Universidad Nacional de Jujuy 36: 91-106.

JuANEZ PÉREZ, Donato

1991 Leyenda del Tunupa y cuentos aymaras. Oruro: Comité Departamental de Etnografía y Folklore de Oruro.

Marzal, Manuel

1985 El sincretismo iberoamericano. Lima: Pontificia Universidad Católica del Perú.

1999 «La transformación religiosa peruana», en La construcción de la Iglesia en los Andes (s. XVI-XX), Fernando Armas, comp., pp. 143-172. Lima: Pontificia Universidad Católica del Perú.

2002 Tierra encantada. Tratado de antropología religiosa de América Latina. Madrid: Pontificia Universidad Católica del Perú - Editorial Trotta.

2005 «La religión quechua actual», en Religiones andinas, Manuel Marzal, ed., pp. 143174. Madrid: Editorial Trotta.

MiLlones, Luis

1998 De la evangelización colonial a la religiosidad popular peruana: el culto a las imágenes sagradas. Sevilla: Fundación El Monte.

Molina Rivero, Ramiro

1996 «La leyenda de Tunupa», en Cosmovisión andina: expresión y sentimiento espiritual andino-amazónico, pp. 401-418. La Paz: Centro de Cultura, Arquitectura y Arte Taipiquiri. 
OCHOA, Víctor

1988 «Santos patronos de los animales», en Raíces de América. El mundo aymara, Xavier Albó, comp., p. 151. Madrid: Alianza - UNESCO - Quinto Centenario.

RICARD LANATA, Xavier

2007 Ladrones de sombra. El universo religioso de los pastores de Ausangate. Lima: Institut Français d'Études Andines - Centro Bartolomé de Las Casas.

RuBINELLI, Ma Luisa

2000 «Los ordenadores simbólicos de la concepción espacio-temporal en el NOA». Cuadernos de la Facultad de Humanidades y Ciencias Sociales 13: 141-159.

SADIR, Marcelo Fernando

2001 «Religiosidad popular en San Salvador de Jujuy: una situación de resistencia colectiva en el mito del Señor de Quillacas»». Ponencia presentada al IV Congreso Inter-regional de Estudiantes de Historia (San Salvador de Jujuy). Ms.

SuÁrez, Hugo José

1999 «Dilemas religiosos en Bolivia», en Subjetividad, dilemas religiosos y medios de comunicación, Natasha Loayza, Hugo José Suárez y Rafael Archondo, eds., pp. 19-61. La Paz: Programa de las Naciones Unidas para el Desarrollo.

TASSI, Nico

2012 "'Dancing the Image': Materiality and Spirituality in Andean Religious 'Images'». Journal of the Royal Anthropological Institute (N.S.) 18: 285-310.

Velasco Maillo, Honorio M.

1989 «Las leyendas de hallazgos y de apariciones de imágenes. Un replanteamiento de la religiosidad popular como religiosidad local», en La religiosidad popular. II. Vida y muerte: la imaginación religiosa, Carlos Álvarez, María Jesús Buxó, Joaquín Álvarez y Salvador Rodríguez, coords., pp. 401-410. Barcelona: Anthropos - Fundación Machado. 